onnistuneesti yhteen. Tämä on sääli, sillä myyttien taustoitus sosiologisesta ja osin historiallisesta perspektiivistä artikkelien alussa tuo kirjan tilastovetoisuudelle oivaa tasapainoa.

Jälkisanoissa on tervetullutta pohdiskelua keskusteluun liittyvistä sosiaalipoliittisista avauksista ja vaihtoehdoista. Jyrkiltä kannanotoilta vältytään huolimatta keskustelun poliittisesta latautuneisuudesta (ks. esim. perustulokeskustelu). Kirja myös välttää harvinaisen hyvin sortumasta poleemisiin väitöksiin tukeakseen näkökulmaansa, mutta toisaalta sosiaalipoliittinen keskustelu jää hieman yleiselle ja varovaiselle tasolle. Kirjassa esimerkiksi sivuutetaan melkein täysin tietyt sosiaalipolitiikkaan liittyvät tekijät, jotka voidaan tulkita osaksi työn prekarisaatiota. Näitä ovat esimerkiksi työttömiä entistä ankarammin työnhakuun patistava työvoimapolitiikka ja pitkäaikaistyöttömien heikentyneet turvaverkot. Toki kirjan jälkisanoissa mainitaan kyseisen politiikan vaarat ja korostetaan työttömyydestä johtuvan syrjäytymisen ehkäisemisen tärkeyttä, mutta tätä keskustelua olisi voitu syventää. Samoin hieman syvällisempi pohdiskelu prekarisaation liioittelun syistä, peräti oman kokonaisen luvun turvin, olisi tuonut kirjaan särmää.

Kirja on kokonaisuudessaan hyödyllinen, melkeinpä olennainen lisäys suomalaiseen työelämän tutkimuskirjallisuuteen. Teos toimii kattavana katsauksena työelämän kiisteltyihin näkökohtiin. Samalla kirjoittajat tuovat näkökohtiin uutta valoa rikkaan tilastoaineiston turvin. Ajoittain ylenmääräisestä myytinmurtaja-asentees- taan huolimatta kirjoittajat onnistuvat haastamaan yleisiä, sosiaalipolitiikan tutkijoidenkin keskuudessa suosittuja, käsityksiä työelämän nykytilanteesta. Sujuvan kielen ja selkeiden taulukkojen välisen sopusoinnun ansiosta kirja luultavasti vetoaa jokaiseen aiheesta ja prekarisaatiokeskustelusta kiinnostuneeseen.

\section{MYÖTÄTUNTO - VIISISÄRMÄINEN MAHDOLLISUUKSIEN MIEKKA}

Minna Mattila-Aalto: $V T T, K M$, $k e-$ hittämispäällikkö, Työtehoseura

Elisa Aaltola \& Sami Keto: Empatia. Myötäelämisen tiede. Into Kustannus, Helsinki. 2017, 330 s.

Elisa Aaltola ja Sami Keto tarttuvat teoksessaan yhteiskunnallisesti aina ajankohtaiseen myötäelämiseen. $\mathrm{He}$ avaavat moniulotteisen käsityksen myötätunnon merkityksistä elintärkeässä asiassa: miten ihmiset kykenevät rakentamaan yhteenkuuluvuutta tuottavia ja elämää kannattelevia vastavuoroisia suhteita nyt ja tulevaisuudessa?

Aaltola avaa myötätunnon monisärmäisyyttä esittelemällä ensin empatian viisi ulottuvuutta: projektiivisen ja simuloivan, kognitiivisen, affektiivisen, ruumiillisen ja lopulta reflektiivisen empatian. Hän kuvaa lukijalle seikkaperäisesti kunkin empatian muodon "hyvässä ja pahassa". Lukijalle muodostuu käsitys siitä, minkälaisia keinoja projektio ja simulaatio ovat yrittäessämme hahmottaa toisiamme entistä kattavammin, miten kognitiivinen empatia auttaa meitä lukemaan toisten mieltä 
ja kuinka affektiivinen empatia auttaa jakamaan kokemuksia ja tunteita ja siirtämään niitä itseemme. Ruumiillinen empatia auttaa meitä tunnistamaan toisen omien kehollisten kokemustemme kautta. Aaltola tekee ymmärrettäväksi jokaisen empatian muodon käytön mahdollisuuksien rajat ja niihin liittyvät ongelmat.

Tiedon lisääntyessä neljästä ensin esitetystä empatian muodosta lukijan mieli kysyy: voiko minkäänlaista empatiaa olla ilman reflektiota ja ilman ympäristöstä ja itsestä tietoista mieltä. Jos kaikki empatian muodot sisältävät reflektion, miten reflektiivinen empatia erottuu neljästä ensin mainitusta? Lukijan myötätuntoinen jännitys kasvaa. Onko Aaltola kömmähtänyt ajatellussaan? Lässähtääkö teksti vai pääsenkö kiipeämään yhdessä Aaltolan kanssa uusiin ulottuvuuksiin?

Aaltola ei petä vaan jatkaa jäsentynyttä ajatteluaan. Reflektiivistä empatiaa kuvatessaan Aaltola kiteyttää empatian muotojen reflektiivisen liikkeen itsen ja ympäristön välillä osoittaen, että reflektiivisyyttä esiintyy yhtä lailla kaikissa empatian muodoissa. Projektiivisessa ja simuloivassa empatiassa liike tapahtuu itsestä toiseen. Ihminen kurottaa kohti toista ihmistä koettaen astua hänen asemaansa ja kuvitellen sen. Kognitiivinen empatia pitää toisen itsestä etäällä. Liike tapahtuu pois toisesta, jotta toisesta voisi saada kirkkaamman näkemyksen. Affektiivinen empatia liikuttaa meitä kohti toisiamme. Toisen tunteet työntyvät meihin ja alkavat täyttää tietoisuuttamme. Ruumiillisessa empatiassa liike soljuu itsestä toiseen ja takaisin. Liike on molemminpuolista, mutta rajapintaa kunnioittavaa.

Reflektiivinen empatia erottuu kuitenkin merkittävästi muista empatian muodosta. Ensimmäinen tietoisuuden taso tunnistaa muiden tunnetiloja tai jakaa niitä. Toinen taso hahmottaa, miten tunnistaminen ja jakaminen suhteutuu oletuksiimme toisista. Reflektiivinen empatia on metataso, jonne voimme nousta reflektoidaksemme muita empatian muotoja ja omaa ajatteluamme tai tunteiden välisiä suhteita. Reflektiivinen empatia saa nimensä sen metareflektiivisesta luonteesta, joka voi paljastaa itsesuuntautuneita, erilaisuuden poissulkevia mekanismeja.

Länsimaisen nykykulttuurin arvioidaan olevan yksilökeskeinen ja kilpailullinen, mikä altistaa yksilöt egoismille ja asettamaan itsensä arvon kriteeriksi. Aaltola perää tarvetta itsensä muokkaamiseen opettamalla ja opettelemalla tunnistamaan empatian kulkuja itsessämme. Mihin empaattiset liikkeemme suuntautuvat? Erityisesti reflektiivistä empatiaa on syytä oppia, mikäli haluamme kehittyä kyvyssämme ymmärtää muita.

Löydän Aaltolan ajattelusta yhtäläisyyksiä integraaliseen systeemiajatteluun. Monikerroksellinen kiihtyvän oppimisen maailma kaipaa keinoja selkeyttää ajatteluamme ja arvottaa maailmaa kestävin tavoin. Integraaliajattelua hyödyntäen voidaan todeta, että kaikki empatian muodot ovat tärkeitä, mutta kaikkien reflektion muotojen uudelleenyhdistäminen on avain kokonaisuuden hahmottamiseen. Muuten ihmiseltä puuttuu kokonaisuuden näkemisen taito. Integroiva tarkastelu on 
välttämätöntä, jotta pystymme kohtaamaan itsemme osana ympäröivää todellisuutta monelta kantilta. Tällä keinoin etenemissuuntamme voi tuottaa hyvinvointia sekä itselle että toisille.

Kirja kysyy inhimillisen etenemissuunnan ohella voimakkaasti, minkälainen on ihmisen empaattinen reflektio muihin luontokappaleisiin kuin ihmiseen. Kirjoittajat nostavat esiin ihmisen suhteen erityisesti kaloihin aluksi hieman koomisiakin mielleyhtymiä herättäen. Reflektio kuitenkin syvenee nopeasti: aihe on maapallon ja eliökunnan kestävän kehityksen kannalta kohtalokas. Taitavasti Aaltola osoittaa sormella ihmiskeskeisen, individualistisen ja uusliberalistisen kulttuurin sokaisemaa lukijaa. Kaikkein eniten tätä kirjaa tarvitsevat tietämättään ne, jotka ovat eksyneet itseensä ja ihmisen ylemmyyteen.

Kirjan toisesta osasta vastaava Keto pureutuu yhteenkuulumisen ydinkysymyksiin. Kuka minä olen? Miten suhtaudun toisiin? Mihin piireihin haluan kuulua? Kedon suuri kysymys "miten tulisi elää ihmisenä maailmassa?" mukailee Aaltolan avaamaa juonta ihmisestä osana suurta luontokertomusta. Itsekseen pärjäämistä korostavassa kilpailukulttuurissa meille opetetaan empatiaa "oikeasti merkitsevien" opetusten marginaalissa. Karrikoiden ilmaistuna ensin opetetaan kovat rationaaliset arvot ja sitten mausteeksi vähän vaaleanpunaista empatiahömppää. Miksi toimimme näin?

Empatian voidaan kokea uhkaavan "tosiasioihin" perustuvaa rationaalisuutta ja oikeudenmukaisuutta, joita meidät on opetettu arvostamaan. Vaikka tunnistammekin egoismin ja individualismin lisääntyneen, emme ota empatiaa riittävän vakavasti, väittää Keto. Samaan aikaan olemme haluttomia ja kyvyttömiä tunnistamaan tunteiden merkityksellistämää maailma, joka motivoi ihmisen toimintaa "tosiasioiden" rinnalla.

Keto korostaa, että empatiassa on kyse ennen kaikkea siitä, millaista kertomusta ihmisyydestä rakennamme. Professori Paul Verhaegeen viitaten Keto esittää uusliberalismin nostavan esiin ihmisen huonoimmat ominaisuudet. Vaikka uusliberalismi tuottaisikin talouskasvua ja teknologisia innovaatioita, sen hintana voi olla sosiaalisen koheesion heikkeneminen, yhteenkuuluvuuden kokemusten rajoittuminen, omanarvontunnon heikkeneminen, ihmissuhteiden välineellistyminen, krooninen yksinäisyys ja vaikeus kokea hyvää tahtoa toisia kohtaan.

Varsin ajankohtainen kysymys juuri nyt on, mikä on empatiaosaamisemme taso yhteiskunnassa, jossa vihapuhe, väestöpolarisaatio ja puhe omissa sosioekonomisissa kuplissaan elävistä ihmisistä on arkipäivää. "Mihin suuntaan haluamme viedä yhteiskuntaa ja ihmisyyttä?", Keto kysyy. Aaltolan tavoin hän muistuttaa, että ekososiaalinen sivistys vaatii huolenpitoa muustakin kuin ihmisistä. Ihmisen tulee laajentaa empatiaa ja ottaa huolenpitonsa piiriin niin eläimet, kasvit kuin eloton luontokin, kultivoida prososiaalisia tunteita ja irrottautua kapeasta oman edun tavoittelusta.

Keto siirtää lukijan yllätykselliseen, pirstaleiseen ja poukkoilevaan lukukokemukseen. Hän poikkeaa voimak- 
kaasti Aaltolan teoreettisesti selkeästä ja hyvin jäsennellystä tyylistä. Tutkijataustaisen ihmisen lukijakokemusta häiritsevät paikoin käsitteiden keskeneräinen avaaminen ja käsitteiden avaamisen täydellinen laiminlyönti kirjassa, jonka tarkoituksena on tiedon popularisointi. Tekstin pirstaleisuus hämärtää sitä, minkälaisina asioiden syy-seuraussuhteet kirjoittajan ajattelussa jäsentyvät.

Tekstin yllätyksellinen eteneminen myös virkistää. Sota esitetään keinona tuottaa yhteenkuuluvuutta yhteisen vihollisen kautta. "Ihminen on julma, maailma on julma", toteaa myös Aaltola omassa osuudessaan. Kedon kirjoittaman tekstin poukkoilu VR:n vuoden 2015 irtisanomisista kolmikymmenlukuiseen esimerkkiin Kellogin työaika- kokeilusta ja edelleen Frederik Taylorin järkeen ja logiikkaan perustuvaan liikkeenjohtoon tekee tekstistä elämänmakuisen. Kun tekstiin ottaa riittävästi integraalista etäisyyttä, Kedonkin tekstistä voi löytää punaisen langan. Kirjasta olisi oletettavasti kuitenkin muodostunut aito kokonaisuus, mikäli Aaltola ja Keto olisivat yhdessä nousseet integratiiviselle metatasolle.

Kirjailijoiden yhteinen sanoma on herättelevä ja haasteellinen: ihmiskunnan on korkea aika pelkän rationaalisen optimoinnin sijaan orientoitua tunnistamaan, minkälaisia tunteita olisi rakentavaa seurata tavoitellessamme kestävää kehitystä. Auttaisiko tämän tehtävän ratkaisemisessa myös sosiaalipoliittinen sivistys? 